\title{
Socio-Economic Factors Influencing Use and Adoption of Family-Sized Bio-digesters as Renewable Energy Sources in Ngoma District, Rwanda
}

Danson Musinguzi ${ }^{1 *}$, Emmanuel Kayinamura ${ }^{1}$, Anne Tumushabe ${ }^{1}$, Daniel Omuna ${ }^{1}$, Emmanuel I. Eniru$^{1}$, Oluwole O. Akiyode ${ }^{1,}$ Edson Mwebesa ${ }^{2}$, Dominic Byarugaba ${ }^{4}$, Twaha A. Basamba ${ }^{3}$, Katongole Hadijjah ${ }^{1}$.

1* Department of Biological and Environmental Sciences, School of Engineering and Applied Sciences, Kampala International University, P.O. Box, 20000 Kampala, Uganda;Emails: mdansonbio@kiu.ac.ug; kayinamura22@yahoo.com; anne.tumushabe@kiu.ac.ug; daniel.omuna@kiu.ac.ug; emmanuel.eniru@kiu.ac.ug; woleakiyode@yahoo.com; hkatongole@kiu.ac.ug.

${ }^{2}$ Department of Economics and Statistics, Kampala International University, P.O. Box 20000, Kampala Uganda; Email: mwebesa.edson@gmail.com

${ }^{3}$ Department of Agricultural Production, College of Agricultural and Environmental Sciences, Makerere University, P.O. Box 7062, Kampala, Uganda. ; twaha@caes.mak.ac.ug;

${ }^{4}$ Department of Biology, Mbarara University of Science and Technology, P.O Box 1410, Mbarara, Uganda; Email: dbbyarugaba@gmail.com

Correspondence: Musinguzi Danson*; Email: mdansonbio@kiu.ac.ug; Tel: +256752 821167

\begin{abstract}
1) Background: The environmental, financial and social questions in Africa remain unanswered up-to-date, with the rapid increase in human population and the demand for fuel energy, trigger the need to generate data on the socio-economic factors influencing the knowledge of use and adoption of family-sized bio-digesters. The increasing prices of fossil fuels and taxes on energy sources require finding the alternative, clean and economical sources of energy for households in developing countries. Moreover, in Africa, the consumption of firewood and charcoal continues to increase, with wood fuel consumption predicted to increase by 2030 to over $140 \%$. The study objectives were 1) to determine the socio-economic characteristics of the people in Ngoma district, 2) to assess socio-economic factors influencing people to use and adopt family-sized biodigesters.
\end{abstract}

2) Methods: Quantitative data collected with semi-structured questionnaires and interviews were analyzed using descriptive statistics.

3) Results: The results show that many households had not realized the potential benefits of biogas use and adoption in Rwanda. The study further found that a number of factors such as household income levels, socio-economic, technological, and institutional influence the household use and adoption of biogas energy.

4) Conclusions: At the end, the study suggests the need for all players such as Government, Non-Governmental Organizations (NGO's) and local communities to work together to provide incentives and favorable environment that can attract individual households to invest in biogas energy production and utilization.

\section{Keywords}

Bio-digesters; Household income levels; Renewable energy; Socio-Economic 


\section{Introduction}

Energy is indispensable to human and the well-being of every society and it is the most powerful keys for a country to measure its economic development. Thus, economic prosperity and quality of life in most countries is/are linked to per-capita energy consumption, and serve as great determinants and indicators of economic development [22]. Similarly, the level of energy consumption in African countries determines the country's economic development $[\underline{16}, \underline{3}]$. Thus, access to clean energy is paramount and brings along with many socio-economic benefits to the citizens in terms of poverty reduction, cost-effectiveness and safeguarding the environment [16, 19]. Relying on wood fuel causes major environmental stresses of deforestation, forest and land degradation, loss of biodiversity, as well as indoor and outdoor air pollution. As a result, the World Health Organization (WHO) attributes 3.5 million premature deaths each year to indoor air pollution caused by combustion of traditional biomass for cooking $[\underline{14}, \underline{23}]$.

In order to eliminate the negative effects of relying on traditional biomass for cooking, the study's specific objectives were to assess socio-economic factors influencing peoples' use and adoption of family-sized bio-digesters and to determine the extent and level of use and adoption of biogas as an alternative renewable source of energy. The hypothesis tested was "Socio-economic factors do not significantly influence the use and adoption of biogas". Nevertheless, the increasing fossil fuel prices and taxes on energy require a study to find an alternative, clean and economic sources of energy affordable and accessible to households and nations in developing country economies.

In addition, the sustainable development goals on energy emphasize that global and national economic and social developments adopt the set core principles guiding the innovative technologies in renewable energy production in order to overcome the present and future energy crisis [12]. In 2015, almost $20 \%$ of the global population in developing countries, approximating to 2.5 billion people, relied on traditional biomass (firewood and charcoal) as a cooking fuel [ 13 , 14], and in some countries, the ration reached as high as $80 \%$ [9]. Although traditional biomass is renewable energy, its traditional use pattern of burning in open fires or use of three-stones or stoves has led to enormous energy waste by utilizing only $5-10 \%$ of existing potential energy [ $[$, $\underline{18}, \underline{4}]$.

Africa is a net energy exporter, but the majority of its population lacks access to clean energy, and many African countries rely on imported energy, yet energy is a key requirement to improve all aspects of human life [2]. Access to energy, particularly modern energy, has remained among the major challenges for most of the developing countries like Rwanda. Rwanda, despite its endowment with the huge potential of renewable energy sources, such as hydropower, wind, geothermal and biofuels, it still suffers from a severe domestic energy problem [17].

Energy demand is a major reason for extensive climate change, resource exploitation and restricts peoples' standards of living. People living in Sub-Saharan Africa lack access to clean, affordable, reliable and environmentally-safe energy and hence rely on solid biomass to meet their basic needs for cooking [6]. This is a core dimension of poverty and a severe constraint to development. Household income levels might not be the only major factor or consideration for investment in biogas technology. Socio-economic and institutional factors operating from the level of the national economy through individual households, all play important roles in influencing rural household decisions to invest in biogas technology. Although the potential need 
is very high in Africa, the technology is at the embryonic stage, with many countries struggling to meet their energy demands. It is a challenge for engineers and scientists to build efficient domestic digesters with the materials available. Although many digesters are constructed, there is the need for additional research and awareness to meet the changing patterns and conditions $[10$, 11].

\section{Materials and methods}

\subsection{Description of the study area}

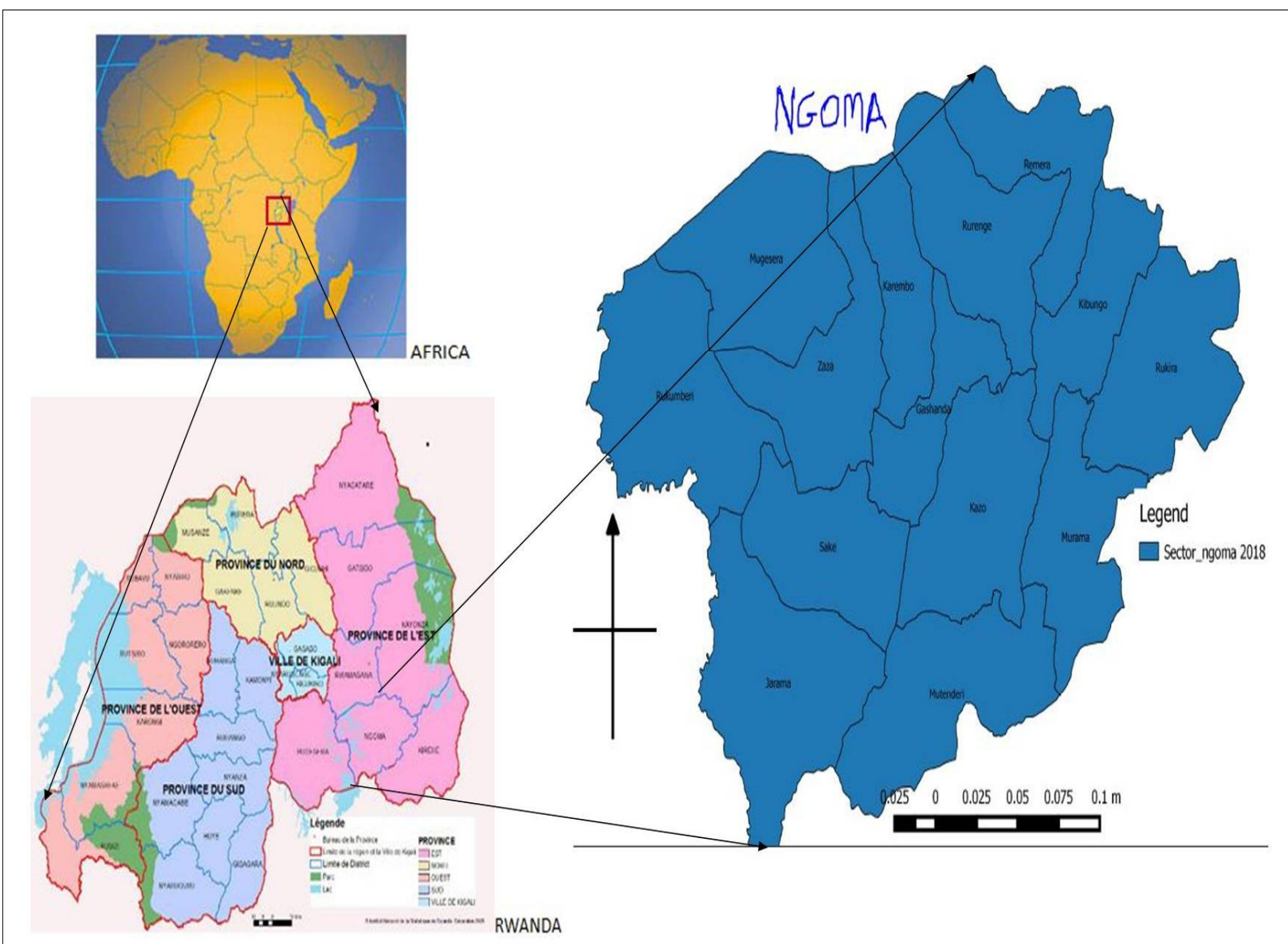

Source: Google Maps, edited by Musinguzi D, using QGIS version 2.14.0, May 2018

Fig.1: Map of Africa showing the location of Rwanda provinces and Ngoma district sectors

Relief and climate: The district of Ngoma (Figure1) is part of the low land areas of Eastern Rwanda, a region essentially marked by hills with low slopes, with an average altitude of between $1400 \mathrm{~m}$ and $1700 \mathrm{~m}$ above sea level. The original relief is a plateau strongly dissected by tectonic movements of the quaternary gully erosion, creating valleys and swamps. The relief of the district influences its climate, which leads to the creation of a temperate climate prevalent in the low altitudes areas. The annual average temperature is around $20^{\circ} \mathrm{C}$. The thermal rhythm is marked in whole by the alternation of the rainy season, with inter-annual variations linked to the general movement of massive air currents coming from the Indian Ocean. 
The Flora and fauna: The dominant natural vegetation of the district of Ngoma is savanna landscapes. It is a typical vegetation of the East African basin, with vast lands of grass with scattered shrubs of various species. The western part of the district is constituted of vast wetlands constituted by depressions of fluvial-lakes of the Akagera that offers a typical landscape of lakes and swamps.

Agriculture and industry: Cattle keeping and cultivation of food crops such as banana, cassava, and beans characterize the district of Ngoma. Although there have been problems of crop pests and diseases such as banana bacterial wilt that has been affecting production, measures have been put in place to curb the scourge, for example, farmers have been provided with resistant crop varieties. Ngoma District does not have many industries except few industries dealing in dairy processing due to the abundance of cattle rearing in the area.

\subsection{Study design, tools for data collection and sample size}

The study used a cross-sectional survey design to traverse the entire Ngoma district and to identify households with family-sized bio-digesters. Using purposive sampling on the selected households, the study used face-to-face interviews with household heads and local leaders in the district involving 105 respondents out of 145 identified during the survey. The study administered semi-structured questionnaires and convened focus group discussions to household heads, to obtain both qualitative and quantitative data.

Table 1: Selected sample size distribution $(\mathrm{N}=145, \mathrm{n}=105)$.

\begin{tabular}{|l|c|c|c|}
\hline Ngoma district & N & Sample size, & Percentage (\%) \\
\hline North & 38 & 29 & 27.6 \\
\hline South & 36 & 25 & 23.7 \\
\hline East & 36 & 26 & 25 \\
\hline West & 35 & 25 & 23.7 \\
\hline Total & $\mathbf{1 4 5}$ & $\mathbf{1 0 5}$ & $\mathbf{1 0 0}$ \\
\hline
\end{tabular}

Data collected using different methods were analyzed using the Statistical Package for Social Scientists (SPSS) Version 16.0 for windows operating system. The factors influencing peoples' ability to adapt and use biogas were analyzed by several techniques including descriptive statistic tests, univariate and multivariate analysis, one way ANOVA, as well as Pearson correlation coefficient matrix. 


\section{Results}

\subsection{The Socio-Economic Characteristics of the People in Ngoma District}

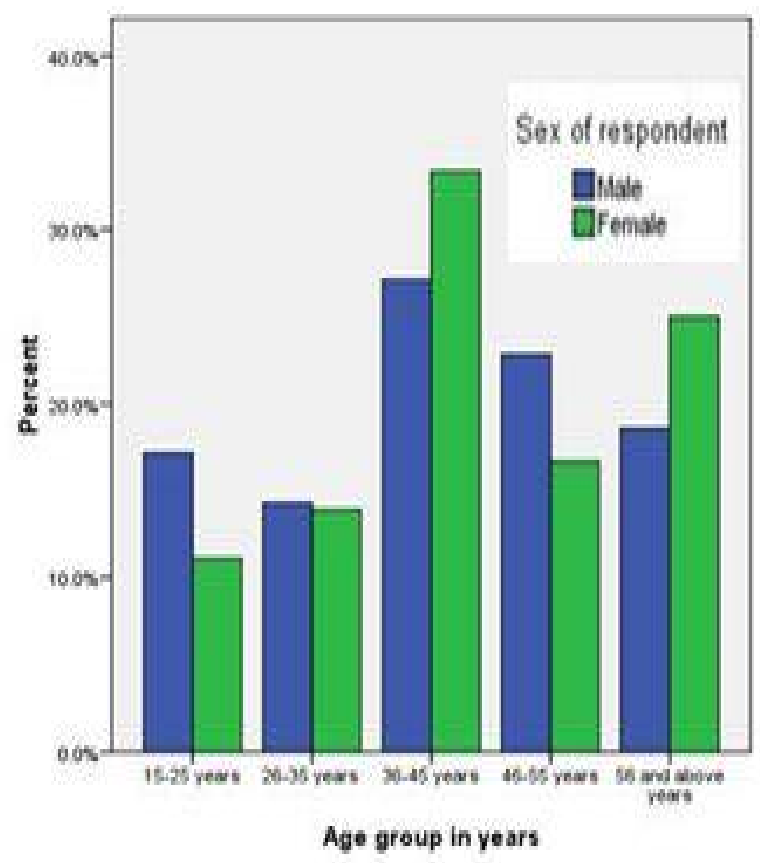

Fig.2. Sex of respondents

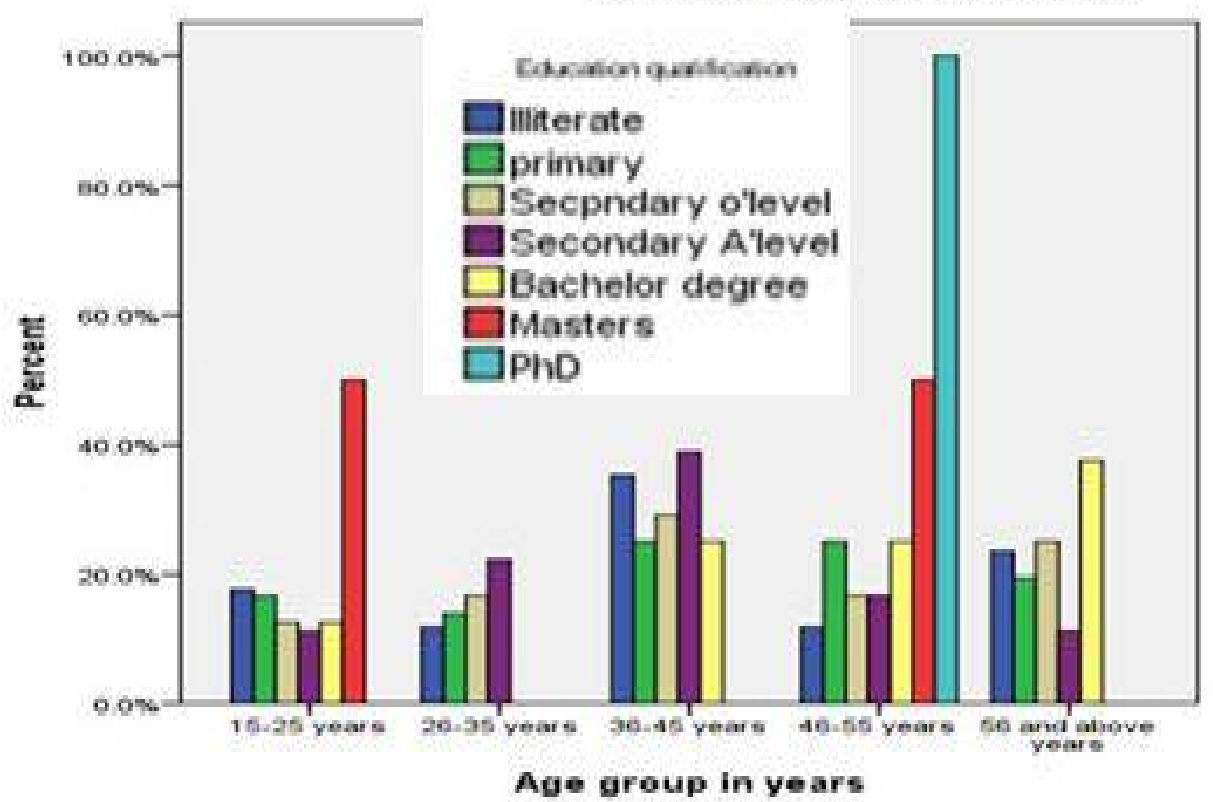

Fig.4. Education qualifications and age groups in years of respondents 


\subsection{Socio-Economic issues and adoption of the use of biogas in Ngoma District}

Table 2: One-Sample Kolmogorov-Smirnov t-Test

\begin{tabular}{|c|c|c|c|c|c|c|}
\hline \multirow[t]{2}{*}{$\begin{array}{l}\text { Socio-economic responses to peoples' use and adoption of } \\
\text { biogas technology }\end{array}$} & \multirow[b]{2}{*}{$\mathrm{T}$} & \multirow[b]{2}{*}{ Df } & \multirow{2}{*}{$\begin{array}{l}\text { Sig. } \\
(2- \\
\text { tailed })\end{array}$} & \multirow{2}{*}{$\begin{array}{c}\text { Mean } \\
\text { Difference }\end{array}$} & \multicolumn{2}{|c|}{$\begin{array}{l}95 \% \text { Confidence } \\
\text { Interval of the } \\
\text { Difference }\end{array}$} \\
\hline & & & & & Lower & Upper \\
\hline Like using biogas as alternative energy source & 38.2 & 105 & 0.00 & 2.36 & 2.24 & 2.48 \\
\hline Biogas is cheaper than other fuels & 38.2 & 105 & 0.00 & 2.32 & 2.20 & 2.44 \\
\hline Biogas is smoke free and convenient & 54.1 & 105 & 0.00 & 3.19 & 3.08 & 3.32 \\
\hline Biogas is easy to use in Ngoma district & 50.8 & 105 & 0.00 & 2.19 & 2.11 & 2.28 \\
\hline Prefer to use biogas to conserve the environment & 37.4 & 105 & 0.00 & 2.46 & 2.33 & 2.59 \\
\hline $\begin{array}{l}\text { Had not adopted use of biogas due to lack of } \\
\text { government policy }\end{array}$ & 28.0 & 105 & 0.00 & 2.50 & 2.32 & 2.68 \\
\hline Biogas use is affordable in my area & 31.2 & 105 & 0.00 & 2.08 & 1.94 & 2.21 \\
\hline Biogas is a renewable energy option & 43.2 & 105 & 0.00 & 3.14 & 3.00 & 3.29 \\
\hline Biogas is easy to make & 26.2 & 105 & 0.00 & 1.97 & 1.82 & 2.12 \\
\hline Biogas cooks better than other fuels & 58.7 & 105 & 0.00 & 3.42 & 3.30 & 3.53 \\
\hline Biogas cooks faster and saves time & 71.9 & 105 & 0.00 & 3.35 & 3.26 & 3.44 \\
\hline Biogas less dangerous and can be used by children & 57.9 & 105 & 0.00 & 3.08 & 2.97 & 3.18 \\
\hline Biogas family sized digesters are cheap and affordable & 38.7 & 105 & 0.00 & 2.12 & 2.01 & 2.23 \\
\hline Biogas keeps the cooking environment clean & 44.8 & 105 & 0.00 & 2.69 & 2.58 & 2.82 \\
\hline Levels of use of biogas from local organic materials & 50.7 & 105 & 0.00 & 2.76 & 2.66 & 2.87 \\
\hline Biogas is the most common source of fuel in Ngoma & 46.2 & 105 & 0.00 & 1.94 & 1.86 & 2.03 \\
\hline $\begin{array}{l}\text { Many people find biogas more reliable to use than other } \\
\text { fuels }\end{array}$ & 36.5 & 105 & 0.00 & 2.31 & 2.19 & 2.44 \\
\hline $\begin{array}{l}\text { Majority depend on biogas as an alternative source of } \\
\text { energy }\end{array}$ & 31.5 & 105 & 0.00 & 1.58 & 1.48 & 1.67 \\
\hline Locally, communities like biogas as it is health risk free & 58.8 & 105 & 0.00 & 3.54 & 3.42 & 3.66 \\
\hline Biogas is used for other purposes than for cooking only & 57.4 & 105 & 0.00 & 3.15 & 3.04 & 3.26 \\
\hline
\end{tabular}

The hypothesis was "socio-economic factors do not significantly influence the use and adoption of Biogas. The value of t-Test obtained was $0.00<\alpha 0.05,2$-tailed, $\mathrm{df}=105$ and the null was significant. The results implied that socio-economic factors are responsible for peoples' use and adoption of biogas technologies as alternative energy sources (Table 2). 
Table 3: A Pearson correlation coefficient matrix of the associations amongst the socioeconomic factors that influence peoples' use and adoption of biogas technology

\begin{tabular}{|c|c|c|c|c|c|c|c|c|c|c|c|c|c|c|}
\hline & SEX & $\mathrm{MS}$ & ED & LBGAS & BGC & $\mathrm{BSCV}$ & DGP & BAFF & BEM & BECB & BCFT & BCEC & BCML & BGW \\
\hline SEX & 1.000 & & & & & & & & & & & & & \\
\hline MS & $0.209^{*}$ & 1.000 & & & & & & & & & & & & \\
\hline ED & 0.028 & 0.057 & 1.000 & & & & & & & & & & & \\
\hline LBGAS & 0.046 & 0.063 & 0.108 & 1.000 & & & & & & & & & & \\
\hline $\mathrm{BGC}$ & -0.070 & 0.013 & 0.073 & $0.407^{* * *}$ & 1.000 & & & & & & & & & \\
\hline $\mathrm{BSCV}$ & -0.051 & 0.046 & 0.165 & $0.419^{* * *}$ & $0.486^{* * *}$ & 1.000 & & & & & & & & \\
\hline DGP & 0.067 & 0.057 & 0.126 & $0.454^{* *}$ & -0.082 & 0.169 & 1.000 & & & & & & & \\
\hline BAFF & -0.109 & -0.045 & 0.020 & $-0.260^{* * *}$ & -0.020 & 0.029 & -0.021 & 1.000 & & & & & & \\
\hline BEM & -0.065 & 0.084 & 0.046 & 0.175 & $0.347^{* * *}$ & 0.010 & 0.039 & $-0.196^{*}$ & 1.000 & & & & & \\
\hline BECB & 0.060 & -0.005 & 0.092 & $0.258^{* * *}$ & 0.218 & -0.015 & 0.035 & $-0.33^{* *}$ & $0.42^{* *}$ & 1.000 & & & & \\
\hline BCFT & -0.136 & -0.044 & $0.211^{*}$ & $0.263^{* *}$ & $0.270^{* * *}$ & $0.446 *$ & 0.213 * & 0.136 & 0.136 & $0.226^{*}$ & 1.000 & & & \\
\hline BCEC & 0.012 & -0.011 & 0.000 & $0.228 *$ & $-0.195^{*}$ & 0.079 & 0.052 & -0.163 & -0.086 & -0.100 & 0.065 & 1.000 & & \\
\hline BCML & 0.053 & -0.026 & -0.105 & 0.028 & -0.001 & -0.116 & -0.126 & 0.012 & -0.046 & $0.238^{*}$ & -0.128 & -0.094 & 1.000 & \\
\hline BGW & -0.133 & -0.055 & 0.099 & $0.203^{*}$ & 0.149 & 0.111 & $0.227^{*}$ & -0.097 & -0.016 & 0.031 & -0.088 & 0.187* & 0.009 & 1.000 \\
\hline
\end{tabular}

*. Correlation is significant at the 0.05 level (2-tailed), **. Correlation is significant at the 0.01 level (2-tailed).

$\boldsymbol{S E X}=$ Sex of respondent, $\boldsymbol{M S}=$ marital status, $\boldsymbol{E D}=$ education qualification, $\boldsymbol{L} \boldsymbol{B} \boldsymbol{G A S}=$ Like using biogas as alternative energy source, $\boldsymbol{B} \boldsymbol{G C}=$ Biogas is cheaper, $\boldsymbol{B S C} \boldsymbol{V}=$ Biogas is smoke free and convenient, $\boldsymbol{D} \boldsymbol{G P}=$ many people have not adopted biogas use because of lack of government policy, $\boldsymbol{B A F F = ~ b i o g a s ~ i s ~ a f f o r d a b l e ~ i n ~ m y ~ a r e a , ~ B E M = ~ b i o g a s ~ i s ~ r e n e w a b l e ~}$

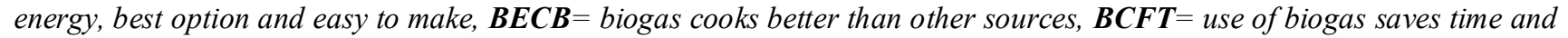
money, $\boldsymbol{B C E C}=$ use of biogas is less dangerous to women , children and keeps environment clean and hygienic, $\boldsymbol{B C M L}=$ the cost of maintaining biogas is low, $\boldsymbol{B} \boldsymbol{G} \boldsymbol{W}=$ Biogas is not affected by weather and its obtained from locally available materials.

\section{Discussions}

The analysis on the rural populations of Ngoma district (Figures 2, 3 and 4) for the demographic and socio-economic characteristics of households was to establish their critical roles in influencing biogas technology use and adoption. A household defined adoption in this study as the production and use of biogas energy from a family-sized bio-digester. Explanatory variables used in the study of the peoples' adoption process for biogas technology were found to 
lack firm theoretical basis because various factors were found to affect the adoption process. Most rural household heads who were farmers considered a variety of other issues beyond socioeconomic well being, including non-economic factors such as peoples' perceptions. A large number of respondents used in the study were male, between the ages of 36-45 years (Fig.4). This was because men were responsible for the most installations of bio-digester materials that in practice require manual labor and traveling long distances for the purchase of equipment. Education levels of people were used to relate to the status of family livelihood, economic activities, and capacity to establish and maintain a family-sized bio-digester. The considerable amount of existing literature on adoption behavior concurs that social, personal, physical, economic and institutional factors are key determinants of the biogas adoption process as an alternative renewable energy source [ $\underline{5}]$.

Social and economic factors were important in determining the answers to the issues that seemed to increase accessibility of alternative and renewable energy sources as a substitute for hydroelectricity and wood fuel to the rural poor in Ngoma district (Table 2). The research findings addressed the following issues in question:-

i) Can the rural poor people afford the initial investment and maintenance costs for family sized biogas digesters in Ngoma district?

ii) Do the poor people have access to finance/credit incentives from the Government of Rwanda?

iii) Is there a commitment from national government authorities in disseminating the biogas technology information?

iv) What is the economic efficiency of households using biogas energy?

The results suggest that between $80-90 \%$ of Ngoma, households rely on wood biomass fuels and $72 \%$ do not use improved energy saving stoves for cooking. These results almost are in line with the findings of World Health Organization of the United Nations [21] on biomass energy for Sub-Saharan Africa. Biogas fuels require money or time to obtain them especially the purchase of materials for construction of family- sized biogas digesters (Table 2). The respondents appreciated that even if the installation requirements for this latest renewable energy technology were still expensive for many households, an integrated biogas system could promote good sanitation and hygiene programme in cooking and lighting, coupled with a multitude of other benefits to society. For example, a rise in agricultural production of approximately to $25 \%$ as sludge from bio-digesters can be organic manures in crop fields, new jobs, household workloads being cut by two to three hours a day as more time is saved using biogas than time spent in collecting fire wood from distant forests, better health and quality of life, fewer trees being cut down for firewood, more fertile soil, higher agricultural production, fewer greenhouse gas emissions, a cut in health costs between 60 and 100 Euros per family per year, a saving of 6,400 tons of fossil fuel per year, a saving of 3 to 4 million tons of wood per year and an annual reduction in greenhouse gas emissions of 10 Mtons of Carbondioxide $\left(\mathrm{CO}_{2}\right)$.

In India as cited in a statement []ㅡ, had established similar findings in a study:

"...promoted as an appropriate rural technology for several decades in India, the application of biogas technology in the rural areas lies in the fact that it enables effective utilization of locally available resources. For the rural poor, this technology provides a clean and convenient fuel at a low cost, being environmentally benign at the same time ....benefits accrue at the user level as well as at the community and global scale." 
However, social stigma was found to exist against the use and adoption of biogas technology by the people in Ngoma district because of cultural beliefs. Many people consider the taste of food cooked by biogas to be inferior to that cooked on a wood or charcoal stove. This suggests a low population of individual households appreciating the use of biogas as an alternative energy source (Figure. 5). On the questions as to whether many people find biogas more reliable to use and whether all the rural people in Ngoma district could afford installation of biogas family-sized digesters, $65 \%$ of the respondents agreed to the reliability of biogas, but $35 \%$ had to disagree, mentioning reasons such as lack of or inadequacies in supply sources for raw organic materials. It can be noted from Table 2 that of the eight household heads interviewed for similar questions, the variations in their responses ranged least in strongly agree and strongly disagree but a large number of respondents had to agree or just disagree with the average of $95 \%$ confidence interval difference of less than $2 \%$. Such results are an indication that biogas as a renewable alternative source of energy for the rural poor in Ngoma has not taken roots in adoption and applicability. Thus, immediate interventions by the government and other bodies are a necessary requirement for this concern.

The study used a Pearson correlation coefficient matrix to study how different socioeconomic and peoples' perceptions were relating to one another concerning the adoption and use of biogas fuels (Table 3). Understanding these associations was necessary for determining the factors that need more attention by the government and other stakeholders involved in promoting the use of alternative energy sources in rural populations such as biogas rather than dependence on hydro electrification that are hindered by financial, technological, and physical factors like the terrain of some mountainous places in Rwanda.

Comparison of ratios of strength of associations within different factors was done using a Pearson correlation matrix (Table 3) and the results obtained were:- Sex/MS $\left(r=0.209^{*}\right)$ weak positive association significant at $\alpha=0.05$ level, 2-tailed, Education qualification (ED) of individual households was associated with (LBGAS $\mathrm{r}=0.108, \mathrm{BGC} \mathrm{r}=0.407 *$ significant at $\alpha=$ $0.05, \mathrm{BSCV} \mathrm{r}=0.419^{* *}$, significant at $\alpha=0.01$, 2-tailed, DGP $\mathrm{r}=0.454^{*}$ significant at $\alpha=0.05$, 2-tailed) while BSCV/LBGAS was at $\mathrm{r}=0.486^{*}$ significant at $\alpha=0.05,2$-tailed, indicating moderately positive associations of these factors, except ED/LBGAS of $r=0.108$ which was a weak positive.

The above associations imply that at least one factor was predicted on influencing a person's attitudes and perceptions on the use and adoption process to biogas technology applications. The other associations established by the matrix included BAFF/MS $\mathrm{r}=0.320^{*}$ significant at $\alpha=0.05,2$-tailed, BEM/BGC $\mathrm{r}=0.347^{* *}$ sig. at $\alpha=0.05$ 2-tailed, BEM/BAFF $\mathrm{r}=-0196^{*}$ sig. at $\alpha=0.05,2$-tailed strong negative correlation, BECB/LBGAS $\mathrm{r}=0.258^{* *}$ sig. at $\alpha=0.01,2$-tailed, BCFT/BGC $\mathrm{r}=0.446^{* *}$ sig. at $\alpha=0.01$, 2-tailed moderately positive, while $\mathrm{BCML} / \mathrm{ED}$ had $\mathrm{r}=0.000$ showing no association and BCML/BGC/BECB had $\mathrm{r}=-0.195^{*}$, sig. at $\alpha=0.052$-tailed $/ \mathrm{r}=0.238^{*} \mathrm{sig}$. at $\alpha=0.052$-tailed respectively. The associations could suggest that each paired factors have an identical influence on the use and adoption of biogas technology by rural populations in Ngoma district. Efforts to introduce biogas digesters should focus in areas where socio-economic factors are most favorable and the choice of digester design should be tailored to maximize the local chances of success.

Smallest size Biogas gas plants having a capacity of $1 \mathrm{~m}^{3}$ can meet the cooking and lighting needs of a generally small family of 3-4 members (Table 4). The bigger family size of a 
6- $\mathrm{m}^{3}$ capacity plant can fully meet domestic needs of a comparatively large family (18-24 members). An increase in the number of cattle owned by a household increased the likelihood of a household adopting biogas. In Ngoma district, cattle are the major source of substances/ raw materials for biogas production. Other sources of raw materials such as crop residues; household and industrial wastes have not been fully harnessed, mainly due to limited technical skills. The number of cattle owned by a household has a direct impact on the number of other important decisions related to biogas utilization and adoption process. It was contended that selecting the size of a biogas plant to be installed depends upon the number of persons to be served or the quantity of cow dung available and stress that selection of unsuitable bio-digester capacity that does not match the availability of the cow dung renders the biogas technology uneconomical [20]. A previous study found that two heads of cattle per household per day were adequate for the necessary substrate required daily for gas production from a family-sized digester (Plates 1, 2 $3,4)$, [1]. Based on the results of this study, where the average number of cattle owned by a household was 5 for biogas users and none for non-users, it was much more easier for a household to afford construction of a family sized bio-digester and sustaining it given a better income or presence of livestock compared to poor households with even no livestock. Although, in some homesteads, it seemed difficult to effectively and constantly feed the dung into the biogas chamber due to the commonly practiced free-range system of rearing cattle that could greatly affect the quantity of cow dung available for biogas production.

\section{Conclusions}

Biogas technology has not been fully embraced in Ngoma district despite the numerous advantages and demonstrated experiences as a good waste management strategy and an alternative renewable energy source. A number of factors were found to influence household use and adoption of biogas technology. These included household income levels which could affect the consideration for investment in biogas technology, socio-economic and institutional factors operating from the level of the national economy through the individual households, all played significant roles in retarding households from making decisions on investing in biogas technology, laxity of government to provide incentives and a favorable environment that could attract individual households to invest in biogas energy production and utilization. Among other socio-economic factors retarding the rapid adoption of households in Ngoma to Biogas technology were cited as the size of cattle herd owned by a household was because cattle provided cow dung as the major substrate to feedstock into family-sized bio-digesters.

\section{Patents}

Author Contributions: Corresponding author Danson Musinguzi prepared the writing of original draft and data collection. All authors including correspondence contributed to writing, proofreading, conceptualization, methodology validation, formal analysis, resources, data collection, writing-review, editing and providing suggestions to improve the quality of this research article.

Funding: This original research did not receive any external funding.

Acknowledgments: I would like to appreciate the efforts of all research assistants who helped in data collection and language translations during this study. I thank all the members of 
the Department of Biological and Environmental Sciences and Department of Economics of Kampala International University for the support rendered to this study and all the entire team of reviewers who made this publication a success.

Conflicts of Interest: The authors have not declared any conflicts of interest and all cited literature have been included in the references.

\section{Appendix A: Photographic Presentations of the Use of Biogas in Ngoma District}

The Plates 1 to 3 below demonstrate different ways and the locally available resources (raw materials) used by the rural people in Ngoma district-Rwanda to make biogas. The designs are suitable for single family-sized bio-digesters to provide energy for cooking and lighting in homes where otherwise hydroelectricity could not be affordable or sustained. However, the other observation included understanding the pre-requisite to the availability of biogas raw materials where a household needed to have some livestock in addition to plant wastes.

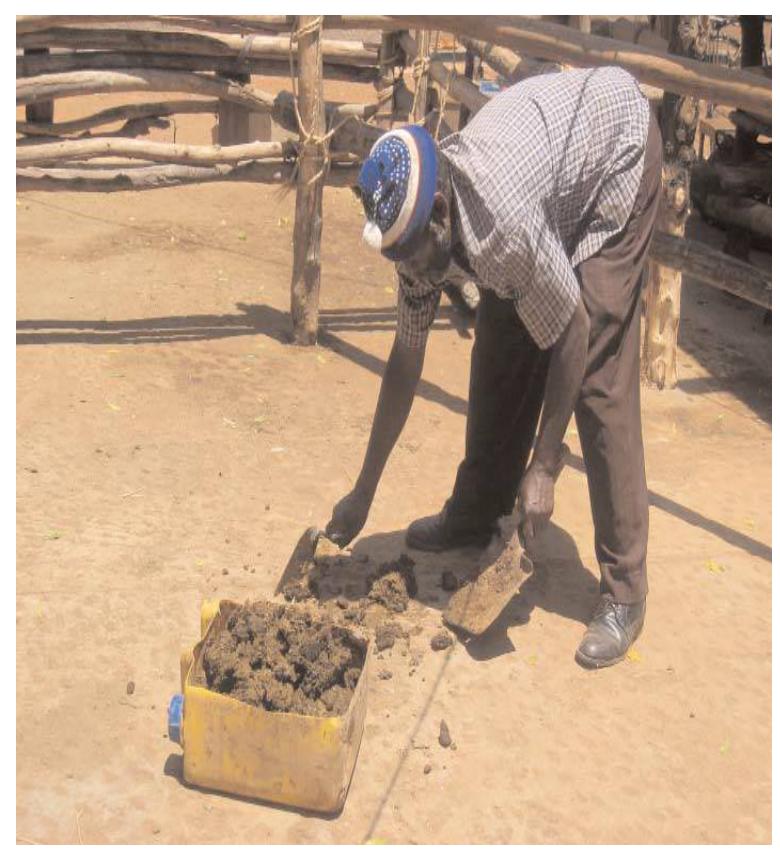

Plate 1: A household head-collecting cow dung (Source: Field study, 2018)

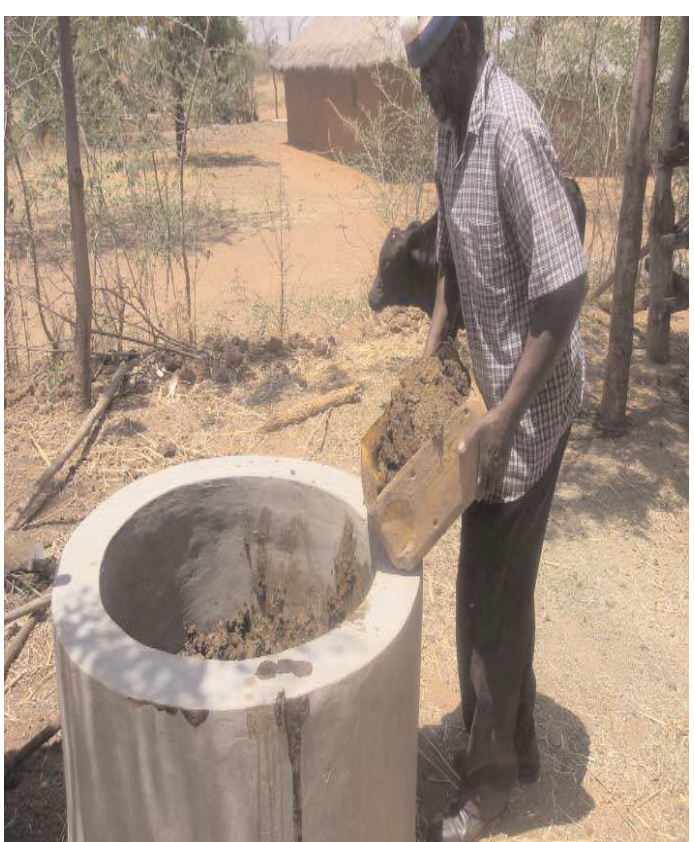

Plate 2: Cow dung put into a bio-digester 


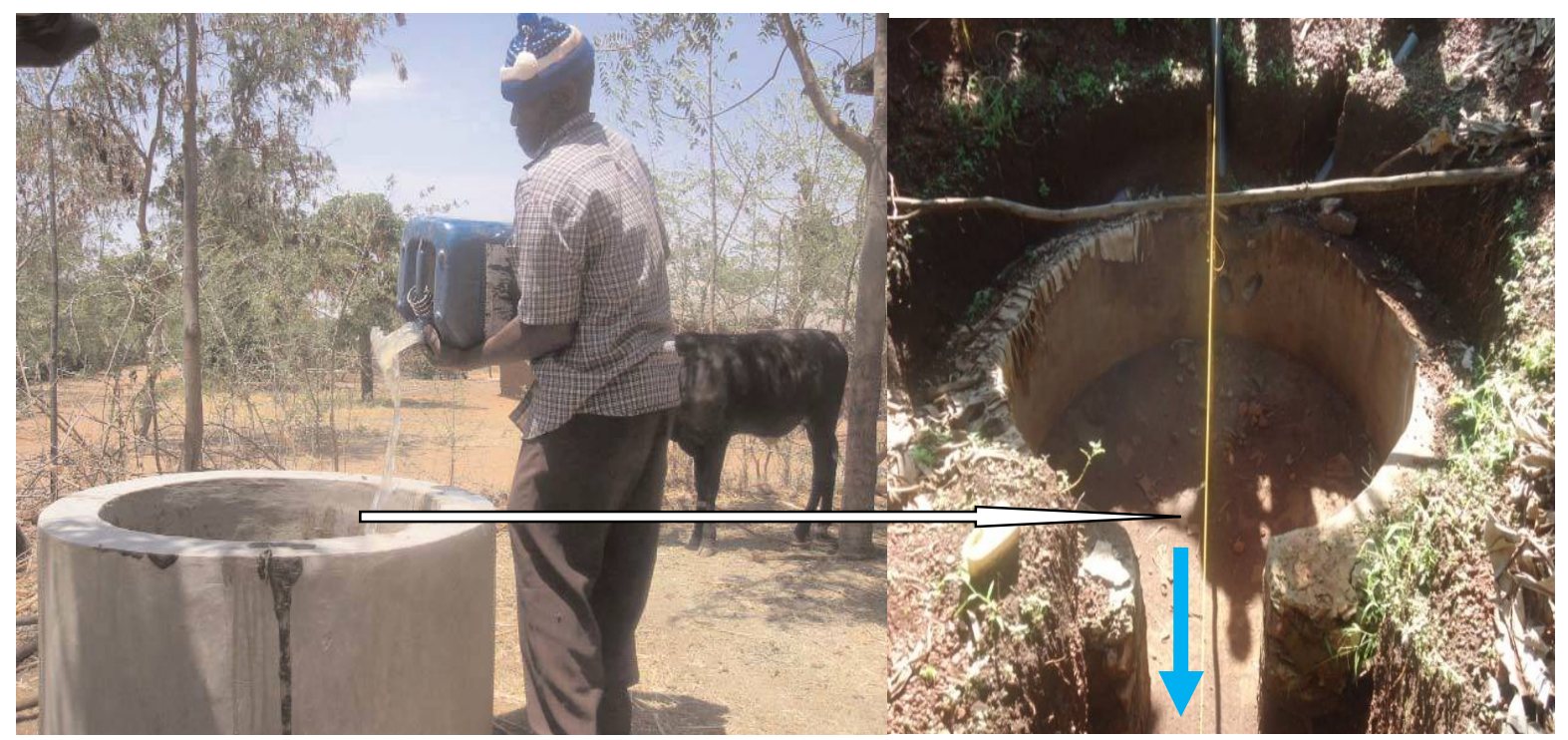

Plate 3: Mixing cow dung with water and internal construction of family-sized bio-digester (Source: Field study, 2018)

A regular supply of water is essential for the operation of biogas plants as this facilitates rapid anaerobic decomposition of organic matter (plate 3). During the construction of a biodigester, it is very important to decide on the size of the digester (Plates 3 and 4). This will depend on how much biogas is needed to meet daily cooking and lighting requirements, availability and amount of livestock manure and water (for example: distance of accessibility of water, number of cows, goats or other livestock available and the materials available on site (bricks) for construction of the bio-digester (Plates 4 (a), (b), and 5 (a), (b) ) below.
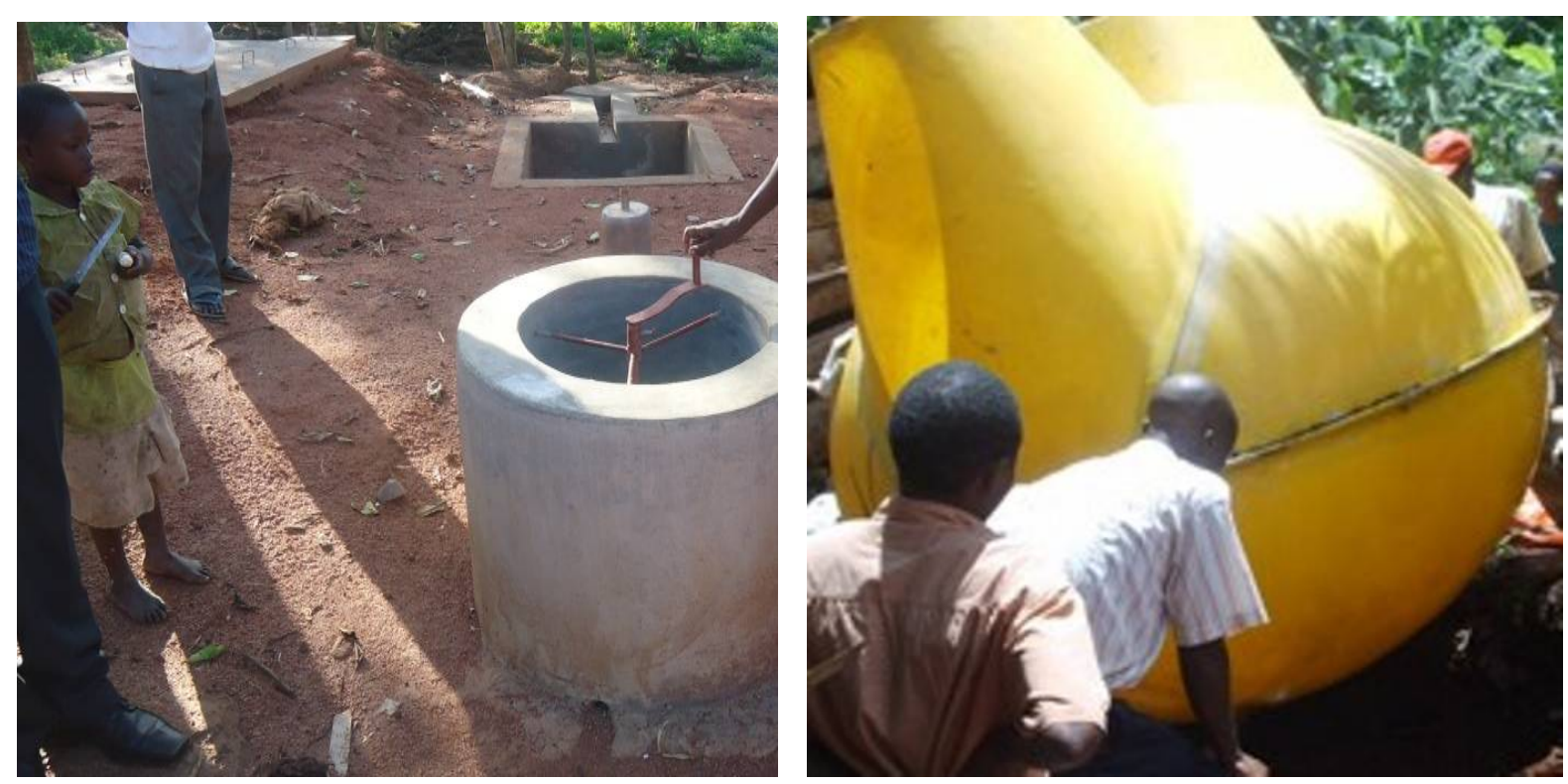

Plate 4: Completed dome-shaped bio-digester (a)

(b) Constructed bio-digester with backfilling

(Source: Field study, 2018) 

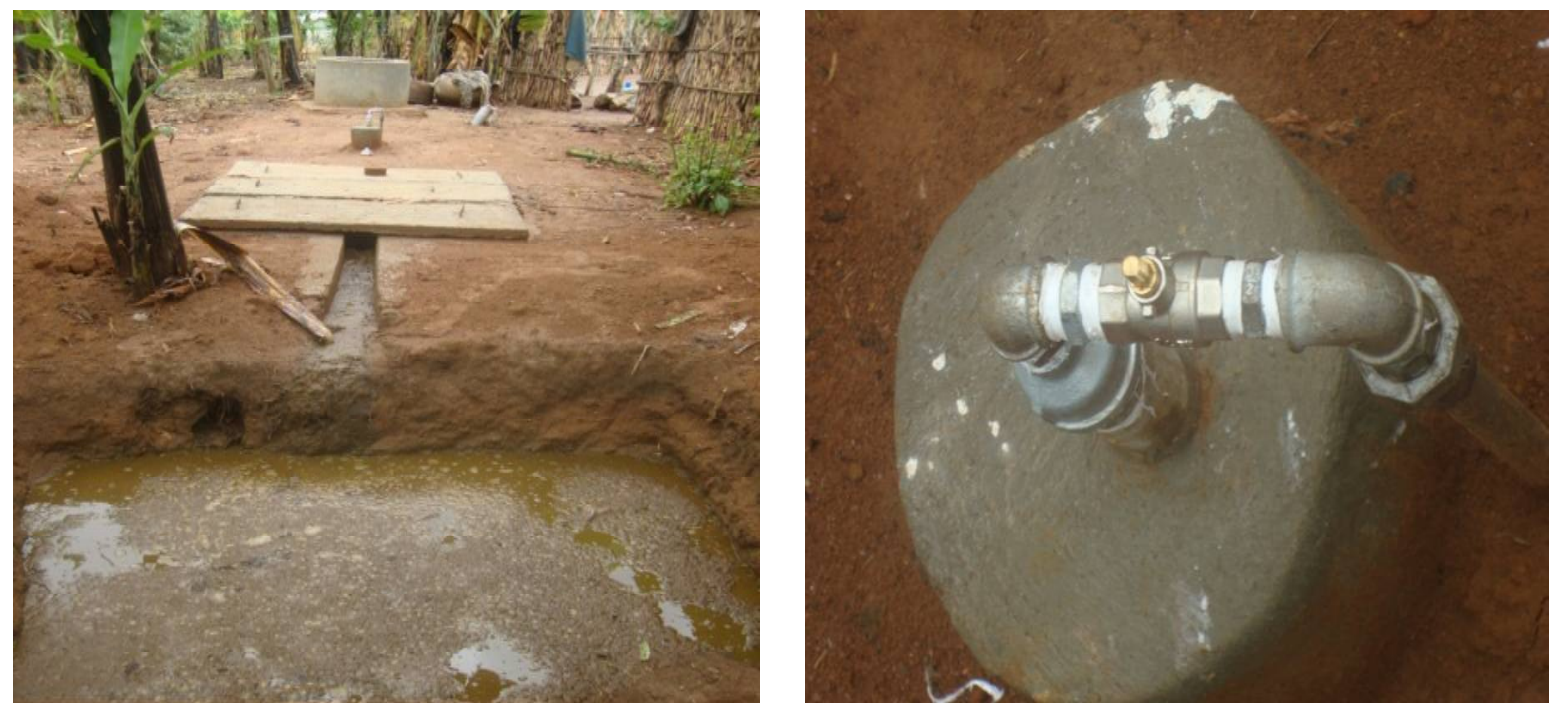

Plate 5: A Completed biogas plant with bio-slurry (a) Biogas plant fiberglass type Turret with the main gas valve (b) (Source: Field study, 2018)

Water mixed with wastes placed in the bio-digester and stirred to make vicious matter then flows into the anaerobic chamber-dome. The temperature of the process is quite important because methane-producing bacteria do their work best at temperatures between $30-40^{\circ} \mathrm{C}$ or 50 $-60^{\circ} \mathrm{C}$. It takes from 2 to 8 weeks to digest a load of waste, depending on the temperature. The leftover slurry that is removed at the outlet for use as fertilizer (Plate 5 (a), while the gas (Biogas) is taped at the gas valve terminal for cooking, lighting, and other purposes Plate 5 (b)). A household bio-digester unit normally has the gas production capacity to meet all the cooking and 2-4 hours of lighting needs for a family.

\section{References}

1. Adeoti, O.; Ilori M. O.; Oyebisi, T. O. and Adekoya, L. O. Engineering design and Economic evaluation of a family-sized biogas project in Nigeria. Technovation, 2000. Vol. 20, 103-108.

2. Amigun, B.; Parawira, W.; Musango, J.K.; Aboyade, A.O. and Badmos, A.S. Anaerobic biogas generation for rural area energy provision in Africa. In Kumar, S. (ed) Biogas. InTech. 2012. Online at: http://www.intechopen.com/books/biogas/anaerobicbiogas- generation-forrural-area-energy-provision-in Africa [Accessed: May 2017].

3. Azad, A.; Rasul, M.; Khan, M.; Ahasan, T.; \& Ahmed, S. Energy Scenario: Production, Consumption, and prospect of Renewable Energy in Australia. Journal of power and Energy Engineering, 2014. 2 (2), 19-25.

4. Bartington, S.E.; Bakolis, I.; Devakumar, D.; Kurmi, O.P.; Gulliver, J.; Chaube, G.; Manandhar, D.S.; Saville, N.M.; Costello, A.; Osrin, D.; Hansell, A.L.; Ayres, J.G. Patterns of domestic exposure to carbon monoxide and particulate matter in households using biomass fuel in Janakpur, Nepal. Environ. Pollut., 2017. 220, 38-45. 
5. Bekele, W. and Drake, L. Soil and water conservation Decision Behaviour of subsistence farmers in the Eastern Highlands of Ethiopia: A case study of the Hunde-Lafto area. Ecological Economics, 2003. 46, 437-451.

6. Brown, V.J. Biogas a bright idea for Africa. Environmental Health Perspectives, 2006. $114: 301-303$.

7. Clark, M.L.; Reynolds, S.J.; Burch, J.B.; Conway, S.; Bachand, A.M.; Peel, J.L. Indoor air pollution, cookstove quality, and housing characteristics in two Honduran communities. Environ. Res., 2010. 110, 12-18.

8. Dutta, S., I. H. Rehman, P. Mahotra and V. P. Ramana. Biogas: The Indian NGO Experience, AFPRO-CHF Network Programme, 1997. New Delhi, Tata Energy Research Institute, Teri.

9. EUEI PDF (EU Energy Initiative Partnership Dialogue Facility). Mapping of Energy Initiatives and Programmes in Africa: Final Report, May 2016, Africa-EU Energy Partnership, Eschborn, Germany.

10. Gijzen, H.J. Anaerobes, aerobes and phototrophs: A winning team for wastewater management. Water Sci. Technol., 2001: 44, 123-132.

11. Gijzen, H.J. Anaerobic digestion for sustainable development: A natural approach. Water Sci.Technol., 2002: 45, 321-328.

12. Habeeb, M. N. and Abdul-Nazar, M.C. Sustainable Development Goals on Energy and Environment: Key Issues in Sri Lanka. Asian Journal of Environment and Ecology, 2017. 5 (2): 1-8, 2017. DOI: 10.9734/AJEE/2017/36556.

13. Hongyun, H.; Shu, W.; Zhijian, Z. Factors underlying rural household energy transition: A case study of China. Energy Policy: 114 (2018), 234-244. Elsevier Journals, doi.org/10.1016/j.enpol.2017.11.052

14. IEA (International Energy Agency). World Energy Outlook. International Energy Agency (IEA), 2016a. Paris.

15. IEA (International Energy Agency). Energy and Air Pollution. World Energy Outlook Spec. Rep. International Energy Agency (IEA), 2016b. Paris.

16. IEA (International Energy Agency), (2014). Africa Energy Outlook A FOCUS ON ENERGY PROSPECTS IN SUB-SAHARAN AFRICA. Paris: International Energy Agency. Retrieved from www.iea.org.

17. Ituze, G., Mwongereza, J.; Abimana, C.; Rwema, M.; Chisale, P. Rwanda Energy Landscape: Foundations for Future Energy Policy, 2017: 1-049-17.

18. Mehetre, S.A.; Panwar, N.L.; Sharma, D.; Kumar, H. Improved biomass cookstoves for sustainable development: a review. Renew. Sustain. Energy Rev., 2017.73, 672-687.

19. MININFRA (Ministry of Infrastructure). Rwanda Ministry of Infrastructure. Retrieved January 13, 2016, from http://www.mininfra. gov.rw.

20. Singh, K. J. and Sooch, S. Comparative study of economics of different models of family size biogas plants for state of Punjab, India. Energy Conversion \& Management, 2004. 45:13291341 . 
21. WHO (World Health Organization). The global burden of disease: Updated 2004. Geneva, World Health Organisation, 2000, World Bank, 1984.

22. Yu, L.; Yaoqiu, K.; Ningsheng, H.; Zhifeng, W.; Lianzhong, X. Popularizing householdscale biogas digesters for rural sustainable energy development and greenhouse gas mitigation. Renew. Energy, 2008. 33, 2027-2035.

23. Zhu, D. Research from Global Sustainable Development Goals (SDGs) to Sustainability Science Based on the Object-Subject Process Framework. Chinese Journal of Population Resources and Environment. 2017: 15 (1): 8-20. 